\title{
O turismo global em Barra Grande (PI): novos processos socioculturais, multifuncionalidade e pluriatividade no espaço rural
}

\author{
Global tourism in Barra Grande (PI, Brazil): new \\ sociocultural processes, multifunctionality and \\ pluriativity in rural area
}

José Maria Alves da Cunha, Marlúcia Valéria da Silva

RESUMO: Pesquisa qualitativa em desenvolvimento, ambientada em Barra Grande - zona rural do município de Cajueiro da Praia (PI), zona litorânea absorvida pelo mercado do turismo global. O artigo objetiva investigar as relações estabelecidas entre os/as nativos/as e turistas, de modo a identificar a multifuncionalidade do espaço rural e da pluriatividade hoje adotada pelos locais ali estabelecidos e os aspectos das novas sociabilidades e identidades em curso. A pesquisa adotou a entrevista diretiva e a observação direta e participante para construir as informações junto à população nativa, além das fontes documentais. Por meio das incursões realizadas, foi possível evidenciar nesta comunidade tradicional de pescadores/as e de pequenos/as agricultores/as que a expansão do turismo global vem promovendo uma diversidade de alterações socioambientais e simbólicas na localidade. As novas realidades incidem sobre os modos de vida e processos identitários dos/as nativos/as, que agora estabelecem relações com turistas de várias partes do mundo, menos por relações simbólicas locais e mais por relações mercantis, comprometendo as referências comunitárias e ressignificando o lugar. A população nativa, hoje inserida numa lógica de racionalização da vida, vem redimensionando suas atividades laborais a partir do parâmetro da multifuncionalidade e pluriatividade rurais, lidando com as resultantes culturais dessas realidades, como as mudanças nos laços tradicionais de reciprocidade. As novas dinâmicas de trabalho ambientadas no mercado dão ênfase às relações sociais assimétricas e de maior complexidade, como o assalariamento e a competitividade, condicionando novos processos socioculturais e outras funções para o lugar, conformando identidades diversas, construídas no campo da cultura global trazida pelos turistas. Ficam também evidenciadas as práticas de consumo de produtos globais, antes alheios às experiências locais.

PALAVRAS-CHAVE: Turismo Global; Multifuncionalidade; Pluriatividade; Modos de Vida; Processos Identitários. 


\section{ABSTRACT}

This qualitative research was developed in Barra Grande - rural area of the municipality of Cajueiro da Praia (PI), a coastal zone incorporated by the global tourism market. The article aims to investigate the relations established between natives and tourists, in order to identify the multifunctionality of the rural space and the pluriactivity currently assumed by the places established there and the aspects of the new sociabilities and identities in progress. The research used the directive interview and the direct and participant observation to build the information with the native population, besides the documentary sources. Through the incursions that took place, it was possible to show in this traditional community of fishers and small farmers that the expansion of global tourism has been promoting a diversity of social and environmental changes in the locality. The new realities focus on the ways of life and identity processes of the natives, who now establish relationships with tourists from diverse parts of the world; relations that are less symbolic local and more related to the market, compromising the community references and resignifying the locality. The native population, currently inserted in a logic related to the rationalization of life, has been redimensioning its work activities from the parameter of rural multifunctionality and pluriactivity, dealing with the cultural result of these realities, such as the changes in the traditional reciprocity links. The new work dynamics, which are set in the market, emphasize asymmetric and more complex social relations, such as salarage and competitiveness, conditioning new sociocultural processes and other functions for the locality, reconciling with the most diverse identities built in the field of the global culture brought by tourists. Moreover, the practices of consumption of global products, before unrelated to local experiences, are also evident.

PALAVRAS-CHAVE: Global Tourism; Multifunctionality; Pluriativity; Ways of Life; Identity Processes.

\section{Introdução}

Atualmente, há uma intensa discussão acerca dos impactos que o turismo causa nas destinações, sobretudo aquelas que possuem características tradicionais, com populações nativas e modos de vida e de costume atrelados ao trabalho com a terra, o rio e o mar. Em grande parte da costa litorânea do Nordeste, é notória a presença de empresas estrangeiras capitalistas de fins turísticos interessadas na exploração desses territórios, visando a instalação de equipamentos hoteleiros de porte internacional, executando o processo de desenvolvimento do turismo global nessas localidades.

Nesse sentido, partindo da perspectiva local, a comunidade Barra Grande, situada na zona rural do município de Cajueiro da Praia, no litoral do estado do Piauí vivencia um intenso processo de desenvolvimento turístico, com a mesma finalidade acima exposta, o que implica em impactos quanto às formas de trabalho, de vida e nos processos socioculturais gerais resultantes da introdução na comunidade do turismo global como principal fonte de renda, mormente apresentada na forma de empregos. É nesse contexto que surgem 
a multifuncionalidade e a pluriatividade como novas formas de interação socioeconômicas neste rural aqui estudado.

A partir disso, a comunidade receptora onde há o latente desenvolvimento do turismo global é acometida por uma série de fatores desencadeados por esse modelo de expansão do mercado de turismo - 0 turismo globalizado -, o qual se constitui num instrumento de territorialização, desterritorialização e reterritorialização das relações no lugar onde é praticado.

Diante disso, o trabalho tem o objetivo geral de investigar as relações estabelecidas entre a população nativa e os turistas, de modo a perceber, identificar e analisar aspectos da multifuncionalidade e da pluriatividade empreendidos pelos/as nativos/as, particularizando a análise do comportamento da população nativa frente aos novos processos de trabalho, identificando os novos processos identitários e as relações sociais advindas desse novo contexto social ensejado pelas práticas de turismo encontradas no local.

\section{Procedimentos metodológicos}

A pesquisa que dá origem a este trabalho está circunscrita sob uma abordagem qualitativa (MINAYO, 2010). A composição do referencial teórico se deu a partir de pesquisa bibliográfica (em livros, relatórios de pesquisa, sites e periódicos) e documental (relatórios técnicos). Assim, o trabalho discute temas como turismo global, comunidades tradicionais, processos de globalização, trabalho e turismo, relações de trabalho, pluriatividade, multifuncionalidade, ruralidades, entre outros. Tais elementos oferecem luz às contingências ensejadas pela exploração territorial própria do turismo global.

A pesquisa também se define como de campo (GIL, 2002), com informações construídas em agosto do corrente ano (2016). A escolha por esse período guarda relação com o posterior período de maior incidência de fluxo turístico na comunidade Barra Grande (mês de julho), tornando possível verificar maior reflexividade dos sujeitos quanto aos objetivos da investigação, condições essenciais à identificação das práticas da pluriatividade e da multifuncionalidade, abordados com maior ênfase neste trabalho.

Assim, procedeu-se com a aplicação de entrevistas não diretivas acerca das temáticas alusivas à proposta do trabalho, que foram obtidas por meio de um aplicativo gravador de áudio instalado no aparelho celular do entrevistador. Esta etapa contemplou 05 (cinco) pessoas entrevistadas, sendo 03 (três) do grupo de trabalhadores/as pluriativos/as e 02 (dois) representantes de grupos familiares que exercem trabalhos relacionados à multifuncionalidade rural. Em vistas de garantir o sigilo de suas identidades e demais procedimentos éticos da pesquisa, os nomes atribuídos aos sujeitos são fictícios. Participaram da investigação: Mariana, 26 anos, que trabalha como auxiliar de serviços gerais em uma pousada; Artur, 25 anos, trabalha na função de função de serviços gerais de uma pousada; Marcos, o mais jovem dos três, 22 anos e trabalha na cozinha de uma das pousadas da região; D. Maria, 55 anos e é a cozinheira do seu próprio restaurante e o Sr. Carlos, 50 
anos, que abriu sua própria pousada e trabalha com a família. A escolha pelas pessoas entrevistadas deu-se de forma aleatória no decorrer da interação no campo, e a participação das pessoas aconteceu de forma espontânea, após convite, tendo sido aceito por estas cinco pessoas, inicialmente. O número reduzido de pessoas se deu pelo fato de a pesquisa estar em desenvolvimento, como parte de uma etnografia para a dissertação de mestrado do autor deste trabalho.

Além das entrevistas, observações e falas que se apresentaram de relevância foram anotadas em um caderno de campo (BRANDÃO, 1982), para auxiliarem no processo analítico desenvolvido. Após esta etapa, os dados foram transcritos, feitos os mapas de leitura, dispostos conforme as expressões faladas, na forma íntegra das gravações, constituindo o corpus sobre o qual recaíram as reflexões. Quanto à análise e discussão dos resultados, a técnica empreendida foi a análise do discurso, procedimento proposto por Bardin (1977). Com isso, as informações construídas por meio das entrevistas foram analisadas à luz da interpretação e do diálogo com a teoria proposta no referencial teórico, de modo a ganhar fluidez e cientificidade. Esse procedimento, na perspectiva de Bardin (1977), possibilita conhecer realidades distintas e que são fundamentais para o entendimento da dinâmica exercidas pelos moradores, nesse caso os nativos da comunidade Barra Grande, que praticam a pluriatividade no espaço multifuncional rural da atividade turística em foco.

A observação direta e participante (GIL, 2008) deu margem à interpretação do cenário em estudo, porque os pesquisadores puderam perceber, na vivência da pesquisa de campo, particularidades e características que requeriam uma visão mais apurada, fruto também de questionamentos adquiridos junto à academia, articulando ambientes diversos de aproximação com o real. Tal estratégia se verificou fundamental para a compreensão do lugar, dos sujeitos e dos processos vivenciados.

\section{Caracterização socioespacial da área de estudo}

A população do estado do Piauí está estimada (para o ano de 2015) em 3.204.028 habitantes, divididos em 224 municípios, segundo dados do Instituto Brasileiro de Geografia e Estatística (IBGE) [2016a]. Quanto à economia piauiense, o destaque está concentrado no setor de serviços, seguido pela indústria e pelo setor agropecuário (IBGE, 2014a).

O litoral do Piauí localiza-se na região Norte do estado, sendo delimitado por 66 quilômetros de orla marítima, que vai desde o município de Ilha Grande (ao Oeste, divisa com o Maranhão), integrando Parnaíba e Luís Correia na porção central, estando, à Leste, o município de Cajueiro da Praia, limitando-se geograficamente com o estado do Ceará. Nesses 04 municípios defrontes ao mar, é passível de identificação uma vasta diversidade da fauna e flora locais, o que é evidenciado pela abrangência do Delta do Parnaíba e pelas inúmeras praias, como a da Barra Grande (em Cajueiro da Praia), que desponta ao mundo como o principal destino do turismo internacional no litoral piauiense. Os turistas são atraídos pela característica natural de plena condição solar e pelos ventos fortes durante quase o ano todo, ideais aos 
esportes radicais, como o kitesurf praticado por estes turistas e por nativos (instrutores), incluídos na lógica da produção turística global.

Situado na mesorregião Norte Piauiense, o município de Cajueiro da Praia pertence à "[...] microrregião do Litoral Piauiense, compreendendo uma área de $281,75 \mathrm{~km}^{2}$, tendo como limites ao norte o oceano Atlântico, ao sul o município de Luís Correia, a leste o estado do Ceará, e a oeste Luís Correia" (AGUIAR; GOMES, 2004, p. 2). O município foi emancipado a partir do "desmembramento de 281,75 km² do território do município de Luís Correia, por meio do Decreto no. 4.810 de 27 de dezembro de 2005" (MACÊDO, 2011, p. 82).

Atualmente, a partir das estimativas do IBGE (2016b), o município de Cajueiro da Praia possui uma população correspondente a 7.451 habitantes. Vale ressaltar a maior predominância da população residente estabelecida no meio rural, no qual, no ano de 2010, quando a população era de 7.163 habitantes, 4.464 eram de rurais $(62,32 \%)$, enquanto $2.699(37,68 \%)$ viviam no meio urbano. Utilizando-se de dados obtidos junto aos relatórios do Sistema de Informação de Atenção Básica (SIAB) - solicitados no Posto de Saúde da Família (PSF) do respectivo território -, no ano de 2013, a localidade pesquisada, Barra Grande, possuía uma população de 2.736 moradores, número equivalente a $37 \%$ da população do município, quando, na época, era estimado em 7.373 habitantes (IBGE, 2016b).

O Produto Interno Bruto (PIB) do município é composto, principalmente, pela produção agropecuária, seguido pelo setor de serviços e pela indústria, com produção incipiente no município (IBGE, 2014b).

A partir de dados do Atlas Brasil 2013 - Programa das Nações Unidas para o Desenvolvimento -, o município de Cajueiro da Praia está na posição 5.253 dentre os 5.565 municípios brasileiros ao registrar o Índice de Desenvolvimento Humano Municipal (IDHM) de 0,546 pontos (apenas 302 municípios possuíam índices piores), colocando o município litorâneo na faixa de "Desenvolvimento Humano Baixo", classificação pertencente à faixa entre 0,500 e 0,599 . Todavia, quando se faz comparação com os dados anteriores pertencentes aos anos de 1991 e 2000, registra-se um exponencial crescimento do IDHM, tendo em vista que os índices registravam anteriormente 0,167 e 0,365, respectivamente (ADHB, 2016). Por meio desses dados, é possível observar que parte desse desenvolvimento (pelo preceito da expansão econômica) se deu a partir da atividade do turismo, que alocou recursos financeiros e fez movimentar a economia local, provendo uma nova dinâmica no município. A maior ênfase desse dinamismo está na comunidade Barra Grande -, o que tem feito aumentar a demanda por emprego e exercido impactos quanto à geração de renda, condições de saúde e educação, mesmo que indiretamente.

Quanto à exploração da atividade do turismo no município, o Ministério do Turismo (MTUR), em 2009, através do Projeto Roteiros do Brasil, instituiu sete regiões zoneadas para atração turística, concernentes a um modelo de desenvolvimento regional do turismo, conhecido por Polos de Desenvolvimento Turístico, em que sua função permitia identificar as diferenças de atratividade e a oferta de bens e serviços, também, 
diferenciados. Estes Polos ficaram conhecidos como Polo Costa do Delta, Polo das Águas, Polo Teresina, Polo Histórico-Cultural, Polo Aventura e Mistério, Polo das Origens e Polo das Nascentes, contemplando toda a diversidade turística piauiense. O objetivo comum desses Pólos é promover o desenvolvimento do potencial turístico do estado do Piauí (SEBRAE/PI, 2012). Por esta proposição, o município de Cajueiro da Praia, juntamente com Parnaíba, Ilha Grande, Luís Correia e Buriti dos Lopes, estão inseridos no Pólo Costa do Delta.

Mais especificamente, Cajueiro da Praia faz parte da Rota das Emoções, roteiro turístico que abrange os estados do Maranhão, Piauí e Ceará, com a perspectiva de desenvolver os municípios abrangidos pelo roteiro, como também os adjacentes. Esse roteiro foi, inclusive, eleito como o melhor do Brasil em 2009 pelo MTUR, devido à boa qualidade da oferta dos bens e serviços utilizados pelos turistas, muito embora a infraestrutura local não contemple a população residente, que não dispõe de esgotamento sanitário público, muito menos o fornecimento de água potável.

A população nativa percebe um incremento maior da renda gerada pelo turismo na sede do município, mas com maior feito sobre a economia particular de Barra Grande, mesmo havendo desigualdade na distribuição e na circulação dos recursos. Por consequência, apesar do efeito multiplicador sobre a renda local, a população nativa é impactada de forma negativa, principalmente pela elevação nos preços dos produtos de consumação básica. Tal realidade tem forçado os nativos a recorrerem a atividades laborais diversas das tradicionais (pesca e agricultura), oferecidas pelo turismo, com vistas à complementação de renda. Dessa maneira, assumem a condição de trabalhadores pluriativos.

Localizada a 12 quilômetros da sede do município, a comunidade Barra Grande é conhecida pelo apelo turístico e pela tradicionalidade dos costumes, evidenciados na pesca artesanal, na agricultura familiar e no modo de vida em que predominam as relações face a face, de interconhecimento, típico desses territórios. Os nativos, na sua maioria, reproduzem suas atividades e obtêm renda através da pesca, da agricultura, do comércio informal e, agora, por meio do turismo (CUNHA; MÉLO; KANITZ, 2014).

A chegada do turismo global tem modificado não somente a dinâmica socioeconômica local, mas também os aspectos físicos, a paisagem natural, a paisagem arquitetônica e, especialmente, a cultura local. Lidando com experiências tão díspares, a proposta do turismo global tem sido uma só: a de uniformização de lugares, práticas, recursos e paisagens, anulando culturas, histórias e demais particularidades humanas de cada ambiente. Este procedimento objetiva atender um turista que consome uma representação e uma paisagem a partir do seu lugar de conforto habitual, sem sustos ou necessidades de readequações circunstanciais.

Visando atender à demanda de turistas estrangeiros, Ferreira (2012b) destaca que em Barra Grande é presente a oferta de bens e serviços que coadunam com o perfil desses turistas, bem como as instalações dos hotéis e a infraestrutura turística, criando um cenário idílico em meio ao contraste social verificado no entorno da comunidade. Tratando da questão em tela, 
Coriolano et al. (2009) e Krippendorf (2001) asseveram que a padronização dos espaços e dos equipamentos no turismo rementem ao turismo global, conhecido por impactar negativamente as destinações turísticas receptoras, principalmente com a introdução do capital e de uma cultura global de consumo.

A partir de uma análise do viés econômico do turismo em Barra Grande, Ferreira (2012a, p. 16) ressalta que a percepção era a de que "[...] 0 turismo era o vilão, e a vítima, por consequência, a 'comunidade local'”. Do mesmo modo, a autora segue afirmando que ao governo coube prestar "[...] subsídios à iniciativa privada e, à comunidade, sofrer os efeitos dessa cruel associação". Assim, percebe-se no turismo desenvolvido no local pesquisado uma associação de interesses entre o empresariado e o Estado, de modo que as necessidades da população são secundarizadas, restando para administração solitária os problemas remanescentes das decisões tomadas sem a sua participação. Tal realidade passa a compor o novo cenário socioeconômico-cultural do qual trata a pesquisa.

\section{Turismo, sociabilidades e identidades}

O turismo visto por uma perspectiva econômica, tem se tornado, ano após ano, como uma relevante atividade econômica, de forte prospecção na geração de emprego e de renda, acrescentando receitas capitais nos mais diversos países do globo, segundo detalham estudos da Organização Internacional do Trabalho (OIT) [2011]. Por consequência, ali são vistos como positivos e promissores os números emitidos pelo setor, fazendo-o aparecer como um importante instrumento de inclusão social no processo de desenvolvimento, o que deveria ser fortemente apoiado pelo Estado e por empresas privadas em condições de investimento. No ano de 2010, a OIT (2011) estimou que o setor de turismo foi responsável por 9,3\% do PIB mundial.

Desse modo, ao tomar como referência a cadeia produtiva do turismo, a geração de um emprego direto no setor gera, indiretamente, 1,5 empregos no mercado turístico receptor. No ano de 2010, a quantidade de empregos no setor de turismo chegou à marca de 235 milhões de postos de trabalho, o equivalente a $8 \%$ dos empregos mundiais, de forma direta e/ou indireta. Assim, a cada 12,3 vagas de emprego geradas uma é no setor de turismo e viagens (OIT, 2011). Mais do que isso, Fernandes (2013, p.245) aponta 0 turismo como "[...] um potencial gerador de empregos e como setor que pode contribuir com a redução das desigualdades sociais", embora destaque que assim se fará se houver harmonia e equidade quanto às formas de desenvolvimento da atividade.

Nesse relevo, convém mencionar o efeito multiplicador da economia do turismo, resultado do intenso movimento de capitais dentro da sua cadeia de produção e execução, direcionando grandes somas de investimentos às localidades turísticas, fazendo movimentar o comércio local de forma em geral nos ambientes receptivos e emissivos de turistas (IGNARRA, 2001; KRIPPENDORF, 2001). Com isso, tanto a localidade emissiva quanto a 
receptiva são acometidas pela nova dinâmica econômica instaurada a partir do turismo.

A expansão do turismo se deu a partir da Revolução Industrial, com o advento da modernidade, seguido do aparecimento de inúmeras tecnologias e de alterações significativas na produção fabril, momento que deu início às primeiras viagens com finalidades turísticas e/ou recreacionais (CACHO; AZEVEDO, 2010). Ainda, Trigo (2000) atribui à sociedade pós-industrial (pós década de 1960) a intensificação do turismo moderno, dando ênfase às mudanças no transporte aéreo, o que fez crescer o turismo de massa em todo o globo.

A partir dessa contextualização geral, surgem diversas vertentes de estudos relacionados ao turismo, abordagens distintas, mas que se alinham ao dialogar com diferentes áreas, como a antropologia, a economia e a sociologia, por exemplo. Dentre as abordagens existentes, destaque para a antropológica de Jafar Jafari (1990), em que sua definição abrange aspectos holísticos da atividade, visualizando o turismo como o estudo do ser humano longe do seu local de residência e de sociabilidade, do trabalho e da indústria que satisfaz suas necessidades e dos efeitos que ambos geram sobre os ambientes físico, econômico e sociocultural do destino receptor. Em outra perspectiva, Cabo (2007, p. 241) descreve o turismo como "um fenómeno contemporâneo y de naturaleza compleja, por ello constituye uma de las vertientes más usuales em la actualidad por lo que representa desde el punto de vista económico, social y político". No âmbito econômico, Santos e Kadota (2012, p. 14) apontam que o turismo pode ser "entendido como elemento ativo da economia, gerando impactos sobre a renda, o emprego e o bemestar social de um país, região ou localidade".

Fernando Oliveira (2008) observa que embora haja inúmeras abordagens, com diferentes concepções e aportes, o estudo do turismo leva em conta objetivos em comum, como: analisar, compreender, planejar e projetar a expansão da atividade turística, de forma que estabeleça maneiras mais brandas de desenvolvimento, muito embora na prática isso não se observe com certa frequência. Essa afirmação prende-se ao fato da grande quantidade de planos, programas e ações que abordam o desenvolvimento turístico sustentável, sem, no entanto, conseguir evitar os impactos previsíveis, denotando que os interesses econômicos persistem se sobressaindo hegemonicamente na equação sustentabilidade versus dividendos financeiros gerados pela atividade em análise.

Contemporaneamente, o processo de globalização, na perspectiva de Schneider (2006, p. 268), vem a ser "[...] caracterizado pela excepcional capacidade com que o capitalismo atual promove ajustes nas condições de tempo e espaço no processo global de produção de mercadorias, possui várias facetas", dentre elas podemos situar o turismo quando os efeitos da globalização se manifestam por meio de diferentes formas de reestruturação econômica, produtiva e institucional, implicando relações entre insiders e outsiders.

Nas experiências da atual reestruturação vê-se que os interesses econômicos globais vêm ditando as regras do consumo também no turismo. 
O capital, visando ampliar mercados e a sua consequente margem de lucro, tem alargado seus limites ao redor do mundo, identificando novos destinos turísticos em todo o planeta, alcançando as mais diferentes sociedades e ambientes naturais. Tais recursos, culturais ou ambientais, são oferecidos como meros produtos para consumo - sem história ou necessidades - a clientes endinheirados que circulam pelo mundo, como argumentam Coriolano et al. (2009, p. 76): "O turismo é claramente uma mercadoria capitalista, movimenta os fluxos humanos ou turísticos, transformando o real por meio de representações. [...] a cidade dos turistas não é a mesma dos residentes, revelando as contradições da sociedade de consumo" e explicitando mais uma vez a pertinência da categoria tomada por Augé (2012), para qualifica-los de não lugares.

Todo o aparato de transformações provocadas no âmbito das interações globais-locais gera uma carga, como coloca Almeida (2007, p. 176) ao falar sobre os efeitos ocasionados pela globalização do local:

Os problemas locais, contudo, são globais: são problemas que dizem respeito a paisagens naturais (mares, florestas, savanas, rios) e aqueles que os disputam - moradores "tradicionais", agências do Estado, megaempresas -, bem como as consequências dessas disputas para o futuro.

Assim, Almeida (2007) considera classificar esses atores como personagens híbridos, sendo difícil descrevê-los como formados por classe ou como camponeses, uma vez que agora seguem a lógica mercadológica, cujas relações são assimétricas e permeadas por interesses do capital, embora essa característica não se generaliza entre todos, como também não marque o fim do rural. Contudo, estas formas globalizadas e modernizadas modificam a ordem social tradicional, subvertendo as relações de parentesco e de vizinhança. Ocorrem, então, as mudanças nos sentidos produzidos, nos símbolos e nos significados do lugar, alterações que promovem as alterações de identidade dos sujeitos.

Especificamente, Augé (2012, p. 73) inscreve o sentido do lugar como um não lugar, conforme explica: "um espaço que não pode se definir nem como identitário, nem como relacional, nem como histórico definirá um não lugar". Em continuação, Augé (2012, p. 73) acrescenta que os não lugares são "espaços que não são em si lugares antropológicos e que [...] não integram os lugares antigos: estes, repertoriados, classificados e promovidos a 'lugares de memória', ocupam aí um lugar circunscrito e específico". Assim, os lugares modificados à luz da exploração pelo turismo global se descaracterizam, conforme o sentido de não lugar dado pelo autor. Do mesmo modo que Augé (2012) se refere aos aeroportos, por exemplo, Panosso Netto e Trigo (2009) asseveram que os resorts nada mais são do que não lugares, são equipamentos que não dialogam com a cultura local, sob nenhuma perspectiva, pois reproduzem um modelo padronizado de turismo encontrado em todo o mundo, confortável aos corações e mentes dos consumidores globalizados. 
Nesta direção, Hall (2015, p. 42) considera que "à medida que as culturais nacionais tornam-se mais exportas a influências externas, é difícil conservar as identidades culturais intactas ou impedir que elas se tornem enfraquecidas através do bombardeamento e da infiltração cultural'. Ao fazer tal consideração, Hall (2015) remonta ao sentido das pequenas aldeias pobres dos países do terceiro mundo que são constantemente invadidas pelo alcance da mídia, recebendo imagens de culturas ricas e consumistas, o que determina a cultura globalizante proveniente das "aldeias globais" e que formam as novas redes de comunicação.

No mesmo sentido, pode-se fazer referência ao turismo global no momento em que turistas de diferentes partes do mundo "invadem" um determinado lugar e inserem um novo ritmo de consumo, de práticas, de moda, de vida, tais fatos modificam a identidade local, No caso aqui estudado, observamos tais constatações, com o agravante de visualizarmos relações de poder assimétricas, cujas relações afirmam e destacam como modelo a ser seguido as identidades que chegam com os turistas. Por esta perspectiva, não há como gerar sustentabilidade para os povos, pois, como aponta Oliveira (2008), temos exatamente o contrário: o turismo se apresenta como ofensivo às localidades receptoras de turistas, promovendo profundas alterações culturais e também a exclusão social, culminando na instabilidade social local e em problemas mais sérios, como a violência, o consumo de drogas, a aculturação, o deslocamento de identidades, entre outros. Entretanto, os autores ressaltam também que há um processo de resistência à globalização. A marca disso, segundo Hall (2015, p. 40), é a evidência de que "as identidades nacionais e outras identidades 'locais' ou particularistas estão sendo reforçadas [...]" (grifo do autor), o que amplia o raio da discussão acerca dos impactos inerentes ao processo de globalização. Assim, é possível destacar que enquanto circulam as novas identificações globais, identificações locais são refeitas e reafirmadas à luz da resistência local. Para os propósitos deste estudo, isso pode ser percebido nas comunidades litorâneas que vêm desenvolvendo o turismo de base comunitária.

Do ponto de vista político, outra questão igualmente importante é que os nativos quase sempre se encontram ausentes do processo de planejamento da atividade, que leva em conta, geralmente, os anseios de investidores e demais interessados externos na exploração da atividade. Nessa direção, Irving (2007, p. 28) vem corroborar que "a população [nativa] de determinado destino turístico é observada como um agente distante do processo de mudança que se estabelece na intervenção dos territórios", o que enseja também a exclusão política pela qual é atingida grande parte das populações nativas dos territórios explorados pela atividade turística de natureza global. 


\section{Impacto antrópico e autonomia local}

Em função das consequências mais comuns que restam às localidades atingidas pelo fluxo de intensas atividades turísticas nas localidades receptoras, os estudos apontam que se mostra necessário um conjunto eficaz de medidas objetivando controlar o acesso de visitantes, podendo se firmar com a existência de ações e programas de conscientização relativos à prevenção de eventuais danos.

Nesse sentido, Ruschmann (2001, p. 17) salienta:

A questão fundamental que se coloca nesse caso é a premente necessidade de controlar o crescimento quantitativo dos fluxos turísticos em todo o mundo, uma vez que os ecossistemas sensíveis ficam irremediavelmente comprometidos quando se ultrapassam os limites de sua capacidade de carga.

Tomando por referências as considerações postas e buscando estabelecer relação com o objeto e o campo estudados, observamos, inicialmente, que a exploração do turismo em Barra Grande é acentuada pelo segmento de sol e praia, ao tempo em que vem crescendo a demanda pelo turismo ecológico na Rota do Cavalo-Marinho ${ }^{1}$, em evidência pela boa conservação do ecossistema presente nos rios Camboa e Camurupim, onde há a maior incidência dos cavalos-marinhos (hippocampus). Atualmente, já desponta a discussão de ambientalistas e nativos acerca da captura dos peixes para visualização turística, devido à possibilidade de gerar dificuldades na reprodução dessas espécies, haja vista a sensibilidade dos animais.

O ecossistema da comunidade Barra Grande concentra muitos igarapés e mangues, ambientes naturais propícios à prática do segmento do turismo pedagógico e de ações de educação ambiental, o que é realizado pela Associação de Condutores Nativos ECOTUR, a qual empreende ações de conservação e de preservação ligadas à sustentabilidade. Contudo, a intensificação do turismo e o aumento do número de visitantes tem contribuído, seguramente, à elevação dos danos causados pela ação antrópica nesses ambientes, tendo em vista a fragilidade das espécies da fauna local, como os peixes e os crustáceos (BIOMADE, 2014).

Os maiores efeitos relacionados ao turismo estão, em sua maioria, ligados à falta ou ausência total de planejamento e de ações mais específicas, o que implica, diretamente, na qualidade dos bens e dos serviços turísticos disponíveis na destinação. Tal consequência é amplamente verificada na comunidade Barra Grande devido, principalmente, a instalação das atividades de turismo a partir de processos decisórios assimétricos e verticais, condição negativa que tem modificado a estrutura social existente, pondo em risco, inclusive, a continuidade do futuro da atividade turística local.

Ainda, por meio da intensificação da ação humana, é possível destacar que essa característica de globalização do turismo transforma comunidades tradicionais em não lugares, emanados pela descaraterização do ambiente 
natural e cultural, associando espaços diferenciados a espaços padronizados, num movimento em que se verificam processos por metade. O espaço tradicional não morre inteiramente, mas não o é mais, efetivamente; enquanto o espaço cosmopolita globalizado não se completa, mas também se verifica cotidianamente. Nem uma coisa, nem outra: um não lugar que falece na potência de permanecer gerando os sentidos originários para as populações tradicionais (AUGÉ, 2012). Em continuação, toma-se como exemplo as cadeias hoteleiras que adotam padrões internacionais tanto nos modelos de arquitetura, como na oferta de serviços, aspectos que paulatinamente são colocados com vigor nos estabelecimentos hoteleiros de Barra Grande, habilitando-a enquanto destino de turismo global. Por outro lado, a população local convive com restrições sanitárias, econômicas, de saúde e educação descoladas da realidade dos turistas que visitarão a comunidade.

No tocante às questões humanas e culturais implicadas nas atividades turísticas, o trabalho de Rui Oliveira (2005) levanta importantes considerações. A partir de uma visão ancorada na sustentabilidade do setor, o autor defende uma maior preocupação quanto à interação dos turistas junto aos nativos, levando em conta os aspectos ambiental, cultural e econômico como parte de uma noção de consumo do turismo comprometido com o desenvolvimento desejável das pessoas.

Neste horizonte, Oliveira (2005, p. 415) critica o turismo globalizado orientado pelo lucro, o que para ele nada mais é do que um tipo de turismo com relação "cliente-funcionário", como mostra:

\begin{abstract}
Então, que tipo de desenvolvimento social essa interação turista estrangeiro-cidadão brasileiro proporciona? Não deveria fazer parte dos objetivos da atividade turística o desenvolvimento sociocultural tanto daquele que visita quanto do visitado? Não seriam essas trocas culturais também responsáveis por estimular o progresso e o bom convívio entre os povos? Ou apenas os aspectos financeiros são importantes para o país?
\end{abstract}

No nosso entendimento, os questionamentos acima apresentados partem das contradições envolvendo a prática do turismo, que, de forma mais concisa, requer mudança no planejamento e na execução da atividade, mais especialmente nos objetivos e pressupostos orientadores das práticas. No tocante ao poder público, as alterações implicam, sobretudo, que a atuação dos gestores e dos administradores se oriente pela melhoria da vida das populações nativas, principais impactadas pelos efeitos desencadeados pelo setor. Isso supõe que os sujeitos nativos sejam gradativamente inseridos no processo turístico de forma direta, ativa e presente, e não como observadores ou coadjuvantes das experiências, apenas. São as ideias gerais aqui expostas que darão estofo para a compreensão da questão de pesquisa, ambientada em Barra Grande, conforme seguiremos abordando. 


\section{Barra Grande: turismo global e novas dinâmicas territoriais}

Uma diversidade de questões é engendrada quando do estabelecimento das dinâmicas globais numa localidade tradicional. No caso deste estudo, que esta realidade se expressa via a presença do turismo global, não se verifica diferente. Novas relações e arranjos sociais, de organização política, novas formas de expressão das atividades laborais e de convivência cotidiana. Em Barra Grande, a dinamicidade territorial da comunidade apresenta variedades quanto a sua forma de ocupação e de uso do espaço, novas práticas culturais e laborais. De um lado, têm-se os antigos moradores, nativos que praticam a pesca artesanal e outras formas tradicionais de reprodução social. Do outro lado, há a presença de comerciantes e de investidores nacionais e estrangeiros que exploram a potencialidade turística da localidade, imprimindo novas relações de trabalho, modos de vida e novos processos societários, marcando novas identidades a partir da introdução do turismo global como preceito mercadológico. Essas características relevam múltiplas facetas do desenvolvimento do turismo como atividade socioeconômica, sendo um dos principais instrumentos de transformação local, bem como alterando a ordem social através da imposição de uma cultura dominante global.

Do ponto de vista do retorno oferecido, verificamos, a partir das entradas em campo, que o discurso hegemônico dos grandes investidores que promete abrir novos postos de trabalho aos moradores locais não se confirma, uma vez que boa parte da população nativa não é absorvida pelos empreendimentos turísticos ali alocados. Além disso, os postos de trabalho gerados não absorvem a população nos empregos de maior expressão. Pudemos confirmar que as vagas destinadas aos moradores nativos são, em sua grande maioria, de serviços gerais, configuradas frequentemente como subemprego, em vista das condições em que se dão. Outro aspecto a considerar é o deslocamento sociocultural provocado, uma vez que o nativo é retirado das atribuições tradicionais costumeiramente assumidas e retraduzidos na condição de assalariado, papel apartado da sua situação social anterior.

No que se refere ao uso do espaço, considerando os modos de vida prevalentes de uma comunidade de natureza rural, é possível reconhecer que a chegada do turismo e as realidades impostas a partir daí, encetam a conformação de uma nova expressão espacial e social. Do ponto de vista normativo e de acordo com o Plano Diretor do Município de Cajueiro da Praia (PREFEITURA MUNICIPAL DO MUNICÍPIO DE CAJUEIRO DA PRAIA, 2008), a comunidade está situada no perímetro rural do município. Como de hábito nas expressões que encontramos no rural brasileiro, ali vige a ausência de serviços básicos (água potável, rede elétrica adequada, saneamento básico, etc.). A justificativa do poder público municipal, reproduzida pelos habitantes vale-se do fato de Barra Grande está situada na zona rural do município, o que impede a implementação de serviços urbanos. $\mathrm{Na}$ perspectiva de Blume (2004), essa característica é encontrada em todo o Brasil, uma vez que as políticas públicas no país levam em conta a diferença entre os meios rural e urbano, o que dificulta a destinação de recursos às localidades rurais que carecem de serviços básicos considerados urbanos. $\mathrm{Na}$ 
verdade, o discurso formal justificador esconde a perversidade das escolhas efetivadas, as quais jogam na condição de não-cidadania as populações rurais do país, em função de princípios político-culturais que conformam o tipo de sociedade que temos conseguido conformar até aqui.

Entretanto, o mais importante a reter é que Barra Grande é uma localidade rural e como tal sofre as consequências desta realidade, muito embora esteja implicada numa particularidade inquietante. No Brasil, os municípios têm estatuto urbano. Cajueiro da Praia, como sabemos, é um deles, muito embora concentrando mais de um terço da sua população numa comunidade rural, que é Barra Grande. Esta, por sua vez, é responsável por grande parte da geração de emprego no município através do setor de serviços, relacionado ao turismo de corte global, evidenciado pelo efeito multiplicador da economia local $^{2}$ associada às atividades do setor. Embora assim caracterizada, Barra Grande persiste, como dissemos, sem estender os serviços básicos à sua população. Para além das realidades de gestão ineficiente dos municípios, como comumente encontramos no país, isso guarda relação com o simples fato da localidade estar qualificada como rural, como já apontamos. Cria-se um paradoxo político e de gestão, em que a localidade que gera a massa de recursos municipais não tem o retorno em serviços por estar situada no meio rural.

Concentrando considerável contingente populacional, Barra Grande também está sob o foco das disputas eleitorais regulares, além de estar sob holofotes por ser a praia piauiense de maior destaque nos roteiros turísticos nacionais e internacionais. Todos esses aspectos imprimem uma situação particular à localidade, mas não conseguem retirá-la da condição de escassez, característica comum aos ambientes rurais brasileiros, embora os nativos convivam com a opulência e os trânsitos globais oportunizados pela prática do turismo. Neste sentido, seguindo Murdoch e Marsden (apud WANDERLEY, 2000, p. 99-100), e situando Barra Grande no campo das reflexões rurais-urbanas, podemos entender a comunidade que surge a partir da exploração turística como um meeting place, um "lugar de confluência de distintos atores coletivos, que estabelecem entre si relações sociais variadas e que passam a disputar o uso da terra e do espaço rural e o controle das instâncias decisórias da vida loca/ ${ }^{\prime \prime}$.

Além disso, no tocante às questões mais particulares tratadas neste estudo, este ambiente rural vem se diversificando em relação à situação de trabalho. O que observamos são novos processos, anteriormente somente encontrados nos ambientes urbanos, na sua maioria trabalhos resultantes da atividade turística de natureza global. Considerando-se a conformação tradicional da localidade, é possível apontar que Barra Grande hoje convive com a realidade da pluriatividade nas práticas laborais dos nativos que, nas palavras de Carneiro (2012, p. 39), "[...] resulta das evidências sobre a inserção plural dos membros das famílias rurais no mercado de trabalho e sobre a diversificação dos usos dos espaços rurais".

As situações apontadas podem ser comumente visualizadas junto a nativos assalariados em empresas do setor da hotelaria; de alimentos e bebidas presentes em Barra Grande, principalmente na função de serviços 
gerais, como já registrado, e outras de menor expressão social. A presença da pluriatividade, como esperado, associa o cumprimento das atividades familiares tradicionais ligadas à terra ou ao mar, mais evidente em Barra Grande, mas também atividades laborais presentes na agricultura familiar, ao trabalho assalariado formal em empresas do trade turístico. Assim, a pluriatividade responde, na prática, como uma estratégia de composição de renda, somando-se à renda invisível familiar proveniente das atividades da pesca e da agricultura. Desse modo, as atividades do turismo se colocam como parte relevante das condições de reprodução dos grupos domésticos, num contexto, como já apontamos, de mudanças socioculturais e novas demandas por ele impostas e de padrão encarecido do custo de vida.

Tratando da pluriatividade, Carneiro (2006, p. 176) destaca, ainda, que esta prática "teria sido 'reinventada' por segmentos da população rural para enfrentar a crise provocada pelo esgotamento do modelo de produção produtivista". No caso em análise, considerando que as famílias antes viviam, com maior ênfase, das atividades da pesca artesanal e daquelas ligadas à terra, como a agricultura. Para o padrão de reprodução social que partilhavam, evidentemente, a pluriatividade não se fazia necessária e nem se aplicava à localidade a ideia de "esgotamento de modelo de produção". Entretanto, o citado esgotamento chega à comunidade via estratégias do capital global utilizando-se do turismo como possibilidade de recomposição de mercados e seus ativos. A pluriatividade experimentada, dessa maneira, advém de uma combinação de fatores externos à dinâmica das famílias, que delas passam a fazer parte intrinsecamente, a partir da nova expressão do trabalho, emprego e padrão de vida a reproduzir. Portanto, o esgotamento uma questão externa - se torna realidade na vida dos locais a partir da interação com os empresários de serviços que aportam na localidade, desencadeando outro esgotamento: o do modelo de reprodução comunitária, sob as bases tradicionais.

Outra característica que recai sobre o fenômeno da pluriatividade reside no fato de atender as demandas dos jovens por emprego, fixando-os no seu lugar de residência. A capitalização, nesse sentido, surge como um fator de atração, porque inculca na juventude a possibilidade de trabalho, diminuindo os efeitos do êxodo rural juvenil. Ainda, Wanderley (2011, p. 103) lembra, também, que a pluriatividade se torna evidente "[...] em função do próprio projeto familiar que está em jogo [...]", destacando as vicissitudes e os ganhos que esta prática traz à unidade de produção doméstica. Entretanto, ressaltamos que, novamente, está em discussão a possibilidade de reprodução comunitária, pois quando ancorados em relações comunitárias de interconhecimento e partilhando estratégias tradicionais de produção/reprodução, os jovens e demais possuíam um lugar no grupo social em que se inseriam. Isso, desde antes, marcava as trajetórias, papeis sociais, responsabilidades e conquistas. Uma vez modificados os modos de vida, os lugares também são descentrados e novos valores são instituídos, bem como condições socioeconômicas, as quais os membros do grupo têm de responder. Assim, a colorida promessa do emprego como algo positivo para que o jovem não saia do seu lugar precisa ser defrontada com a realidade de que é o próprio esquema de geração de emprego (ou subemprego) próprio 
das investidas de expansão do capital, que, contraditoriamente, impõe aos jovens a necessidade de ir embora. É também por este prisma que a pluriatividade se reapresenta como expressão do esgotamento de um modelo de produção; não das comunidades, mas do capital global.

Presente também na discussão acerca do espaço rural, a questão da multifuncionalidade, marcando a compreensão das novas ruralidades, o que para Carneiro (2002, p. 224) compreende a ocupação do "[...] espaço rural por outras atividades econômicas não-agrícolas associadas à revalorização do mundo rural como espaço de lazer ou de residência (secundária ou principal) para segmentos de camadas médias da população urbana". O fenômeno se mostra relacionado tanto às novas expressões do capitalismo no mundo e às formas encontradas para enfrentar e gerenciar tais realidades, quanto aos modos de vida experimentados nas grandes cidades. Desse ponto de vista, os problemas advindos da urbanização e os rebatimentos na vida das pessoas vêm reconfigurando a cidade como lugar promissor, promotor de satisfatórias condições de existência humana. Questões como a violência urbana, o estresse cotidiano, a artificialização das paisagens, dentre outros, têm estimulado cada vez mais a busca pelo contato com a natureza e com os modos de vida simples. Esse movimento vem impulsionando as pessoas a buscarem o ambiente rural propriamente dito ou a sua retradução, a partir de releituras operadas pelo turismo rural e oferecidas como serviços de lazer e de turismo. Isso significa dizer que na atualidade o espaço rural não é mais reduzido ao simples espaço agrícola ou de uso majoritário por atividades ligadas direta ou indiretamente à agricultura, configurando-se como um espaço multifuncional.

Atualmente, percebendo o elevado número de empregados em funções não-agrícolas no campo, Carneiro (2002, p. 225) assevera que a pluriatividade "associada sobretudo às atividades de serviço [...] combinada à noção de multifuncionalidade, alimenta a discussão sobre as características da ruralidade nos dias atuais", desfazendo ainda mais a noção do rural como assemelhado à agrícola.

Dois fatores são apontados por Carneiro (2002) como responsáveis pelas novas dinâmicas das ruralidades vistas na sociedade brasileira contemporânea. O primeiro deles é a comunicação estabelecida por meio da ampliação da mobilidade (construção de estradas, transportes coletivos, maior facilidade de aquisição de automóveis) e dos meios midiáticos/virtuais de comunicação (Internet, televisão, rádio). O segundo remonta ao movimento neo-rural, realidade que promove a "transformação do campo em espaço de lazer ou mesmo de residência principal para integrantes de camadas médias da população urbana que buscam uma qualidade de vida diferente (e 'melhor') daquela a que estão submetidos na cidade" (CARNEIRO, 2002, p. 226). Nesse último, percebe-se uma nova representação social sobre o "rural", cuja ideia do atraso, do isolamento, do vazio até recentemente obrigatoriamente presentes e definindo este espaço, são substituídos por conceitos de qualidade de vida, proteção da natureza, relações face a face etc., sustentando, agora, uma valorização positiva da natureza e da cultura local. 
Nessa nova reconfiguração do rural que dá estofo à multifuncionalidade e ao movimento neo-rural, surge o turismo como uma das atividades que também ressignifica o lugar. Para Carneiro (2002, p. 226), "introduz mudanças nos hábitos e práticas de vida das pequenas localidades", e também instala processos de aculturação que produzem efeitos negativos e positivos sobre a população nativa. Como consequência disso, Carneiro (2002, p. 226) destaca "a ampliação (e diversificação) do mercado de trabalho em certas regiões de vocação turística, e a criação de necessidades e desafios para a população desses territórios que se tornam socialmente cada vez mais complexos".

Essas condições são impostas a partir da nova organização socioeconômica estabelecida pela multifuncionalidade e pela pluriatividade, consequentes dos novos trânsitos e verificadas na localidade, que agora passa a ser concebida mais como um destino receptor turístico do que o lugar de vida de um determinado grupo humano. No caso que aqui nos interessa verificamos ocorrer tais realidades, oferecendo, portanto, estofo à reflexão apresentada por Carneiro, 2002 e outros estudos da área.

\section{Resultados e discussões}

A construção de informações, por meio de entrevistas, caderno de campo e documentos, nos permite apontar a multifuncionalidade do espaço estudado, com profusa pluriatividade, objetivada a partir de atividades associadas ao turismo na região do litoral piauiense, se expressando mais fortemente na própria comunidade Barra Grande, campo da pesquisa, que se destaca pela vocação turística do segmento de sol e praia, de natureza global.

Apesar das condições físicas e da infraestrutura deficientes para a rápida expansão da atividade, tem ocorrido um largo desenvolvimento do turismo nos últimos vinte anos, o que tem trazido uma série de investimentos financeiros ligados à rede hoteleira, muitos com padrões bastante exigentes, tendo em vista que a maior parte do público consumidor pertence a camadas de consumidores mais elevadas economicamente, embora haja, ainda que em menor expressão, grupos de turistas e excursionistas ligados ao turismo de massa, com menor poder aquisitivo, mas estes não se constituem como público alvo dos investimentos referidos.

Quanto à nova dinâmica territorial, o diálogo estabelecido nas entrevistas possibilitou conhecer o comportamento dos nativos informantes acerca da mesma e dos novos processos de trabalho instaurados a partir da expansão da atividade turística global na comunidade. Nessa perspectiva, uma das entrevistadas, Mariana, descreve como tem vivenciado essa nova condição:

Olha, moço, o bom de ter arrumado um emprego é a certeza do dinheirinho no final do mês, né? Quando eu ajudava minha mãe com as coisas de casa e meu pai com a lida na pesca, eu num tinha muita chance de ganhar um dinheiro pra comprar minhas coisinhas. Tudo era muito difícil e o dinheiro 
[que recebia] era muito pouco, mal dava pra comprar as coisas pra dentro de casa. Agora, não. Agora o salário que ganho aqui na pousada dá pra eu me ajeitar. Então, tá bom, né?

A informante relata a dificuldade de obtenção de renda frente às atividades familiares tradicionais, principalmente por pertencer ao gênero feminino e, por isso, não dispor de uma função específica de trabalho que possibilitasse adquirir uma renda fixa mensal, o que é mais fácil às pessoas do gênero masculino, neste caso. Destacamos a condição de gênero em função da natureza do trabalho realizado - a pesca - e de sua localização na cultura local, o que seguramente aprofunda as dificuldades para o gênero feminino. Entretanto, queremos destacar a pluriatividade em Barra Grande, remontando ao mesmo sentido dado por Carneiro (2002, p. 225), a qual afirma que "essa prática pode significar tanto um mecanismo da estratégia de reprodução social de famílias sem condições de se manterem exclusivamente com a atividade agrícola" ou de se relacionar às mudanças no padrão de exploração econômica vigente na localidade, no caso em tela, a introdução do turismo como atividade econômica. No caso de Mariana, o que a qualifica como pluriativa é a continuidade das jornadas em atividades no grupo familiar, ajudando os pais nas atividades tradicionais, como destaca: "ei, moço, mas em casa eu ajudo meu pai e minha mãe... num esqueci deles, não, viu?".

Analisando do ponto de vista econômico-financeiro, ainda cabe mencionar o efeito multiplicador sobre a renda dos nativos (KRIPPENDORF, 2001) a partir de uma nova base econômica promovida pelo turismo, o que não quer dizer que isso esteja melhorando a vida da população nativa, mas apenas acrescentando renda monetária à localidade, por enquanto.

No que se refere ao deslocamento de identidade como parte do processo de desenvolvimento do turismo global nas comunidades locais, observamos o mesmo a partir do contato direto e da interação social que há, ainda que de forma limitada e reduzida, e do contato hostil na relação entre empregado e cliente. É o que identificamos quando Mariana diz que "aos poucos a gente vai imitando o jeito deles, né? Eles se vestem com roupas bonitas, os cabelos são diferentes e a gente acha bonito. Muitas das minhas amigas gostam de imitar eles, eu imito pouco". Ao tempo que fala, é possível perceber o esforço que faz para falar bem dos turistas, como se pertencessem a uma cultura superior à sua, evidenciando a condição assimétrica dos contatos. Nesta situação, não há, à primeira vista, um esforço na relativização das culturas, provocando a hibridização cultural, no sentido dado por Canclini (2008, p. 24) quando a entende como "processos socioculturais nos quais estruturas ou práticas discretas, que existiam de forma separada, se combinam para gerar novas estruturas, objetos e práticas", obviamente democratizando os contatos culturais.

O que verificamos foi o movimento no sentido da superação de uma cultura (a local pela global), o que incide contra a manutenção dos traços culturais tradicionais. Dessa monta, esse aspecto remete às descontinuidades (GIDDENS, 1991) dos processos identitários resultante da modernidade e do 
avanço e do interesse do capitalismo, como parte de um extenso processo de globalização, homogeneizando as culturas, como assevera Hall (2015).

Em situação semelhante à de Mariana quanto à pluriatividade, Artur se apresenta como um trabalhador assalariado que encontrou na atividade do turismo uma "chance" de "mudar de vida", como coloca:

[...] não dava mais pra viver da pesca, de ajuntar uma coisa aqui e acolá pra ganhar uns trocados que nem dava pra ajudar direito [nas despesas] em casa. Antigamente até dava muito, mas agora o peixe ficou mais difícil de pegar. Aí, apareceu uma chance de mudar de vida e eu não pensei duas vezes. Aí, eu trabalho aqui e nas horas vagas eu ajudo em casa, também, né? Porque só isso aqui (o trabalho na pousada) num dá, não. A família é grande, tem irmão pequeno, já tem filhos, aí, a coisa complica mais, né?

Assim como Mariana, Artur compõe sua renda com o emprego e as atividades tradicionais, de modo pluriativo. Com isso, podemos apontar que a pluriatividade é presente entre os jovens de Barra Grande, o que garante a permanência juvenil na comunidade, conforme apontam as palavras de Artur: "o bom disso é que a gente não precisa mais ir embora, aqui mesmo tem emprego", o que pode ser compreendido, nesse caso, como "a reversão do ritmo do êxodo rural-urbano" (CARNEIRO, 2008, p. 17), uma vez que tem possibilitado o retorno de alguns nativos que partiram em busca de trabalho em outras cidades e estados. A realidade realçada por Artur surge como uma das razões para que os locais indiquem como positiva a presença dos empreendimentos os quais acessam os postos de trabalho, sendo-lhes furtado o entendimento de que esta presença também gera nova situação social, como a proletarização juvenil, por exemplo, que é quem gera e justifica a imprescindibilidade do emprego na atualidade. A partir dessa nova configuração encontrada neste ambiente rural, há de se presumir que novas sociabilidades se engendram, em face da interseção de diferentes atores, "de dentro" e "de fora".

Em meio às percepções positivas, como em relação ao incremento da renda monetária e a permanência dos jovens na comunidade nativa, o desenvolvimento do turismo global traz, também, consequências negativas de maior monta, mais facilmente identificáveis pelos nativos, levando-os a relativizar as supostas vantagens. Para Mariana, o turismo possibilitou muitos acréscimos à comunidade, mas também concentrou o aumento de problemas:

A gente vê o turismo e pensa que tudo são flores, mas não é, não, viu? Tem as drogas. Maconha é fichinha, agora é crack, é pó (cocaína). Eu não sei como fica, porque muitos jovens são fracos, aí acabam gostando e quando vão ver, não saem mais desse mundo. Olha, pior ainda é a prostituição. Um bocado de meninaszinhas aí já são preparadas pra eles (turistas). Dão bebidas pra elas, dão presentes, aí fica mais fácil. 
Esses impactos negativos no ambiente de Barra Grande já foram encontrados por outras pesquisas, embora sem maior aprofundamento por não contemplarem os objetivos do estudo (CUNHA; MÉLO; KANITZ, 2014). No cotidiano local, o que se pode ver é que ao longo do tempo a situação não foi corrigida e a população nativa se vê ameaçada pela falta da gestão pública que não se ocupa de planejamento de ações sociais, visando dar maior controle e maior rigor quanto à operacionalização da atividade, que visivelmente acumula prejuízos socioambientais. Dessa desigual relação, convém destacar que o turismo, ao mesmo tempo em que proporciona maiores investimentos econômicos e maior circulação monetária, gera e impulsiona impactos negativos sobre a sociedade e o meio ambiente. $O$ descontrole de tal situação pode resultar na rejeição da atividade por parte da população nativa que antes não estava exposta aos referidos problemas, conforme conclui Oliveira (2008).

De forma mais evidente, Krippendorf (2001, p. 87) complementa:

O resultado é que se chega a uma incompreensão mútua, em vez de um entendimento entre os povos. Às vezes, chega-se ao confronto, em vez do encontro. $\mathrm{E}$, até mesmo, no pior dos casos, ao desprezo, em vez do respeito. Os turistas desprezam estes autóctones "subdesenvolvidos" os quais, em contrapartida, desprezam estes estrangeiros "liberados".

Um aspecto relevante na comunidade Barra Grande a partir da intensificação do turismo, sobretudo quanto aos jovens, está nos processos culturais e identitários. Quanto a isso, Artur revela que grande parte de seus amigos são influenciados pela cultura estrangeira, adotando desde roupas diferenciadas a bonés, cortes de cabelo, danças, falas, entre outros, denotando uma nova forma de consumo, baseada em artigos estrangeiros, o que pouco dialoga com a cultura tradicional local, conforme segue seu relato:

Aqui na Barra Grande todo mundo quer imitar os gringos. Tem moleque aí que nem quer mais paquerar as meninas daqui, não, só querem se aparecer pras de fora. Eles se vestem igual os turistas, tudo de boné e roupa parecida. Quem vê pensa... [risos]. Eu, não. Eu valorizo meu lugar, sou como os antigos e acho que está certo (sua escolha), porque temos que valorizar o nosso, né? Mas eles, não. Eles só querem ser igual os gringos.

Desse modo, pode-se retomar a discussão de Hall (2015) acerca das identidades partilhadas, que se estendem aos consumidores de produtos globais ao utilizarem as mesmas mensagens e imagens, mas, nesse caso, atentando ao encontro de indivíduos díspares que ocupam, ainda que por tempo limitado, um mesmo lugar, o qual está sendo deslocado pelo processo de globalização que tende a homogeneizar os processos sociais e culturais, deslocando-os a uma nova ordem determinada por uma cultura dominante $e$ de consumo. É pertinente ressaltar este aspecto dominante de uma das 
culturas, posto que nas interações as questões de ordem política não ficam esquecidas e no mercado global de identidades a valoração de cada uma vai estar posta, como se refere o entrevistado.

Assim como Artur, Mariana também traz considerações acerca do discurso hegemônico utilizado pelas empresas investidoras na comunidade da Barra Grande, no que se refere à oferta de emprego à população nativa:

Você vê o meu caso, mas nem todo mundo tem a mesma chance [de conseguir um emprego]. Eu tô aqui mesmo, moço, porque eu preciso. Não que o trabalho seja ruim ou pesado, é porque é diferente demais de tudo o que a gente já fez, porque aqui é cheio de umas palavras em inglês, e a gente às vezes ainda tem que falar com eles (turistas). No início era mais pior, porque diziam que tinha emprego pra todo mundo, mas pra nós [nativos] só sobrava era limpar chão, na construção, no pesado mesmo, viu? Quem fica com os emprego (de melhor qualificação e que são melhor remunerados) é as pessoa de fora... [...], de Parnaíba tem é muita gente, porque tem que falar inglês, e eles têm estudo, a gente num tem muito, não.

$\mathrm{O}$ argumento mais comum que se apresenta no mercado em relação ao apresentado por Mariana é que a população local não está qualificada para acessar as vagas de emprego abertas com os empreendimentos (CORIOLANO et al., 2009), tanto no turismo quanto ao processo que ocorre nas fazendas de soja na região do Sudoeste Piauiense (SILVA, 2013). Notadamente, a população local é qualificada para o seu modo de vida tradicional, seja a agricultura ou seja a pesca. $O$ que as contingências socioculturais impostas pelas empresas vêm revelar são os choques culturais, os quais não tem feito parte nem do cálculo econômico, nem do cálculo de risco e prejuízos para os locais. Claro está que, portanto, que se trata de uma escolha política no que respeita a que tipo de desenvolvimento local se busca e a quem o mesmo beneficiará. Tanto é assim, que, no litoral e nos cerrados, muda a atividade econômica, mas não mudam as contradições resultantes das ações implementadas, partidárias do desenvolvimento capitalista que apenas objetiva maximizar seu lucro. Dessa realidade origina-se a desigualdade social a partir da concentração de renda na mão de poucos, além das demais questões levantadas.

Outro fator elencado pelas pessoas informantes diz respeito às alterações que a comunidade sofreu quanto ao ritmo e aos modos de vida, considerações que refletem uma nova dinâmica do espaço social local. Neste sentido, Marcos revela que "a gente agora tem uma nova rotina, porque temos horários, viu? Antigamente, não, a gente nem ligava pra isso. Agora, a gente convive com todo tipo de gente, e isso mexe com o nosso jeito de ser, eu agora vivo como se fosse na cidade grande". As palavras de Marcos demandam refletirmos sobre o que Lefebvre $(1978$, p. 15) trata como tecido urbano, "que define la "sociedad urbana" va acompañada de una lenta egradación y desaparición del campo, de los campesinos, del pueblo, así como de un estallido, una dispersión, una proliferación desmesurada de lo 
que antaño fue la ciudad", manifestando um significado de urbanidade, tanto espacial como social. Não desejamos com isso apontar que Barra Grande esteja se configurando em uma sociedade urbana, mas chamar a atenção para o ritmo das trocas rurais e urbanas, além da assimetria que localizamos nas narrativas. As falas permitem-nos inferir que o sentido do tecido urbano apontado por Lefebvre (1978) age sobre Barra Grande, alterando os tradicionais sistemas de costumes e valores, introduzindo novas práticas sociais e espaciais, cujos resultados determinam um ritmo cotidiano distinto daquele ao qual o nativo estava habituado e que vem sendo modificado pela cultura global que ali aterrissa.

O que observamos em relação aos três informantes acerca do tema da "pluriatividade", é que todos asseguram que o assalariamento obtido junto às empresas turísticas do ramo da hotelaria contribuiu para um ganho monetário maior, com destaque ao acréscimo de renda no grupo familiar. Entretanto, Artur, Mariana e Marcos continuam a ajudar suas famílias no desempenho de funções ligadas à pesca, à pequena produção de animais e à comercialização de alguns produtos de origem agrícola, ainda que de forma bastante residual. Quanto à multifuncionalidade e à pluriatividade, encontramos que as famílias nativas desenvolvem outras atividades econômicas ligadas, agora, ao turismo, de modo que a atividade agrícola ou a lida com a pesca não sejam, a priori, as de maior monta. Tal realidade de trabalho (re)configura um espaço social diverso do tradicional, mostrando um rural em adaptação às novas dinâmicas socioculturais trazidas pela cultura e economia globais. Por esta razão, este trabalho estabeleceu contato com duas famílias de moradores nativos que resolveram diversificar suas atuações, aderindo às novas dinâmicas locais decorrentes do turismo, resultando no investimento em empreendimentos próprios como meio de reprodução do grupo familiar em um cenário cada vez mais difícil à população nativa.

Inicialmente, as famílias entrevistadas perceberam que poderiam ganhar dinheiro modificando seu espaço de convivência e algumas de suas práticas. Tratam-se de pequenos investimentos nos setores de alimentos e bebidas e da hotelaria, que despertaram a atenção dessas famílias nativas, as quais passaram a formatar planos de abertura de negócios próprios, comportando economicamente os membros da família. Assim, foram criados dois estabelecimentos comerciais: um restaurante e uma pousada.

O restaurante, a princípio, traz relação direta com as atividades tradicionais ainda em execução pela família, como aponta D. Maria, matriarca da família:

[...] foi uma ideia do meu filho. Ele viu os pessoal de fora abrindo um monte de restaurante, né? Aí, ele teve a ideia da gente montar uma coisa parecida, sabe? Porque eu já sabia cozinhar e fazia aqui e acolá uma comidinha pra vender. Meu marido, coitado, saia pro mar e voltava com os peixe dele, mas nem sempre isso dava pro nosso sustento, tinha que vender uma parte. Aí, o Pedro (filho) foi e inventou da gente mexer com isso. Hoje trabalha nós tudin [da família], num tem ninguém de cara pra riba. 
Além das questões já apontadas, ressaltamos a perspectiva da multifuncionalidade deste rural em análise. Aqui, então, prevalece a ideia de Wanderley (2000) quando propõe a emergência de uma "nova ruralidade", acompanhando os percalços aos quais está exposta. Do ponto de vista das práticas locais, percebemos que esta não é uma relação livre, mas constituída em única saída frente à expansão do capital e da ordem geral da globalização dos processos que ali aportam derivados do turismo. Assim, neste rural vivido, a dimensão local fica subsumida às novas realidades, impostas pelas novas dinâmicas. Aos sujeitos, resta a adaptação. Devido ao aumento da demanda nos períodos de alta estação (carnaval, férias de julho, final de ano), a família contrata profissionais extra, privilegiando os nativos, com assalariamento temporário. É quando migram dos antigos papeis de vizinhos e assumem os novos papeis de patrões, selando as novas relações mercantis na comunidade.

Alheia à violenta dinâmica, D. Maria sente os efeitos da globalização sobre o negócio da família, afetando não apenas a maneira de trabalhar, mas, também, os costumes locais e, até mesmo, a própria cultura tradicional, como relata:

[...] é complicado, aqui a gente luta muito, todo dia. Olha, eles quer que seja do jeito deles [turistas]. Tem que ter máquina de cartão [de crédito]. As comida tem que ser do gosto deles e nós acha tudo isso complicado. A gente faz é um peixin frito, uma coisa simples, né? Porque nós num sabe fazer aquelas coisas chiques que eles come. A gente quer que eles coma igual a gente, que prove do sabor das nossa comida mesmo.

$\mathrm{Na}$ fala de $\mathrm{D}$. Maria evidencia-se um processo de deslocamento de atributos identitários, imposto aos moradores nativos. No caso em tela, há o complicador pelo fato dos locais ocuparem o lugar de quem precisa vender uma mercadoria, em tese, precisando se ajustar com menos resistência. Todavia, mesmo neste contexto, há resistência por parte de alguns: "eles têm é que entender que aqui é do nosso jeito" (fala de Pedro, filho de D. Maria). Exemplos como este só reforçam a ideia de que nestes lugares explorados pelo turismo global, persiste uma forte resistência por parte da população nativa, no sentido de alguma manutenção da cultura local; processos que legitimam a sua identidade, cada vez mais ameaçada pelos fluxos globais de consumo, como aponta Hall (2015).

Outro exemplo de resistência cultural e de identidade é encontrado na família comandada pelo Sr. Carlos, que abriu uma pousada familiar. Ele conta que foi difícil, no início, pela dificuldade de recursos, estruturar o espaço físico de sua propriedade e adequá-lo para transformar em um estabelecimento que pudesse receber hóspedes, conforme seu relato:

Ah, foi difícil, muito difícil. As pousada dos gringo era tudo chique, viu? Mas, também, era tudo igual [a padronização global]. A nossa, não. Aqui é tudo natural, feito mesmo pela 
gente, então é mais parecido com a gente, tem a cara da nossa comunidade [...]. Eu acho mais bonito, porque valorizamos o que é nosso, da nossa terra, do lugar onde nascemos e se criemos.

Aqui, mais uma vez, observamos a cultura globalizante imprimindo o modelo homogeneizador sobre os processos culturais e identitários locais. Mais ainda, no caso do Sr. Carlos há um destaque quanto à noção de não lugar. O turismo global cria instalações padronizadas para comportar o seu público, os quais pagam por serviços e produtos compatíveis ao seu poder de compra. Estes estabelecimentos, geralmente, fogem à regra da arquitetura local, bem como utilizam materiais e outras matérias primas originárias de outras regiões do mundo, desprezando os materiais em abundância no local por serem considerados como de baixo valor. Adotam um elevado nível de acabamento e um gosto de uso do espaço diferente do que se pratica na comunidade. No caso especial dos resorts e das grandes cadeias de hotéis, em relevo, são espaços comuns e padronizados, os quais produzem encontros a partir da reunião de um punhado de pessoas em relações, muitas das vezes, anônimas. Isso leva à constatação do aparecimento dos não lugares, pois se difere do sentido de lugar dado por Augé (2012, p. 73), o qual argumenta que "o lugar se completa pela fala, a troca alusiva de algumas senhas, na convivência e na intimidade cúmplice dos locutores", o que não é observado, em geral, na maior parte do público turístico que frequenta resorts.

No que se refere aos frequentadores, destacamos a estranheza que se efetiva em relação aos trabalhadores e vizinhos de tais estabelecimentos. São mundos inteiramente justapostos, que não se fundem. Os sujeitos praticam o mesmo espaço, mas sob perspectivas, necessidades, desejos e poderes diferenciados. Dessa relação pode nascer tanto a necessidade de copiar a cultura que chega, como de resistir a ela, como muito claramente deixam perceber as narrativas dos sujeitos entrevistados. Isso confere ao estudo pontos de encontro com a literatura acessada, no que respeita às relações globais versus locais e seus possíveis desdobramentos de subsunção ou resistência. Claro, neste caso trazemos também as narrativas evidenciando a assimetria das relações verificadas.

\section{Considerações finais}

Diante das informações construídas e discussões empreendidas, nos foi possível apontar que há evidências de uma nova dinâmica socioeconômica e cultural verificada na comunidade Barra Grande, após a operacionalização do turismo global. Este fato vem modificando não apenas o ritmo de vida da população nativa, mas o espaço rural e os processos socioculturais ali existentes.

Do ponto de vista das pessoas, ficaram evidenciadas as críticas quanto aos prejuízos identificados como diretamente decorrentes da implantação de atividades regulares e massivas do turismo na localidade. Foram apontados os efeitos prejudiciais à sociedade local e ao meio ambiente, pois se trata de uma atividade econômica que faz uso ostensivo das relações sociais, do solo, 
da água e da paisagem para o seu melhor desempenho e consolidação econômica. Essa realidade configura um quadro de multifuncionalidade do espaço rural, conforme as categorias analíticas permitem enxergar. Não obstante a clareza com que os locais percebem os problemas, também encontramos avaliações positivas do turismo, em função da nova atividade econômica "solucionar" as dificuldades que foram surgindo quanto à renda das famílias; entretanto constatamos que a promessa do pleno emprego não se confirma, deixando de fora do processo inúmeros sujeitos locais, penalizados pelas inserções de agentes de fora, em função desses apresentarem melhores credenciais para os postos de trabalho de melhor nível oferecidos. Além disso, a performance dos salários, também em função do subemprego disponibilizado, não tem sido capaz de dar o suporte necessário às famílias. É neste contexto que temos o aparecimento da pluriatividade que associando atividades laborais tradicionais com aquelas advindas das práticas do turismo global tem possibilitado a reprodução social do grupo familiar. De forma mais ampla, a capitalização dos jovens hoje proletarizados aparece como uma "grande chance" para mudarem de vida, acenando para a realidade de que as atividades tradicionais poderão ser superadas por ocupações funcionais de pouca habilidade nos empreendimentos hoteleiros e do setor de alimentos e bebidas.

Enquanto isso, identificamos uma população nativa que não está inteiramente de acordo com tantas intervenções em seu território, impondo uma dinâmica socioespacial que impacta não apenas a forma como devem trabalhar e prover o sustento, mas o seu modo de vida e, sobretudo, sua visão de mundo e suas identidades. Isso tem possibilitado o surgimento de alguma reflexividade por parte das pessoas nativas, no sentido da resistência das identidades locais e de sua cultura tradicional. Conforme hoje se encontram, se mostram hibridizadas, numa relação assimétrica, portanto sentidas como ameaçadas pela cultura de consumo do outro que ali aporta, resultante do turismo global operacionalizado na localidade.

Assim, a comunidade Barra Grande vive um dilema provocado pela inserção de ordem mormente econômica que vem sofrendo, com repercussões sociais, culturais e ambientais, o que vem transformando a realidade da população nativa.

Nesse sentido, é possível apontar que um minucioso e detalhado plano de desenvolvimento participativo, que partisse da escolha política de priorizar as necessidades materiais e simbólicas da população local, poderia melhor equilibrar a atividade, garantindo alguma convivência cultural emancipatória e equidade social dos implicados. Assim orientada, a exploração comercial do turismo poderia ocorrer levando em consideração a manutenção das tradições locais e dos processos socioculturais e identitários, o que responderia por um esperado desenvolvimento oportunizado pelo turismo, propiciando a interação e o encontro desejáveis entre turistas e nativos, dentre outras questões de igual monta já abordadas. 


\section{Referências}

AGUIAR, R.B.; GOMES, J.R.C. Projeto cadastro de fontes de abastecimento por água subterrânea, estado do Piauí: diagnóstico do município de Cajueiro da Praia. Fortaleza: CPRM - Serviço Geológico do Brasil, 2004.

ALMEIDA, M.W.B. Narrativas agrárias e a morte do campesinato. RURIS, v.1, n.2, p. 157-188. 2007.

ATLAS DO DESENVOLVIMENTO HUMANO NO BRASIL (ADHB). Perfil Cajueiro da Praia, PI. 2014. Disponível em: < https://goo.gl/a9YfN3 > Acesso em: 14 jul. 2016.

AUGÉ, M. Não lugares: Introdução a uma antropologia da supermodernidade. Tradução de Maria Lúcia Pereira. 9. ed. Campinas, SP: Papirus, 2012.

BARDIN, L. Análise de conteúdo. Tradução de Luís Antero Reto e Augusto Pinheiro. Lisboa: Edições 70, 1977.

BIOLOGIA MARINHA DO DELTA (BIOMADE). Trilha ecológica. 2014. Disponível em: < https://goo.gl/BnEKXB > Acesso em: 10 jul. 2016.

BLUME, R. Território e ruralidade: a desmistificação do fim do rural. 2004. 179 f. (Dissertação de Mestrado), Programa de Pós-Graduação em Desenvolvimento Rural, UFRGS, Porto Alegre, 2004.

BRANDÃO, C. R. Diário de Campo: a antropologia como alegoria. São Paulo: Brasiliense, 1982.

BRASIL. Instituto Brasileiro de Geografia e Estatística (IBGE). Estados@. 2016a. Disponível em: < https://goo.gl/UowfhJ > Acesso em: 15 jul. 2016.

BRASIL. Estados - Piauí. 2014a. Disponível em: < https://goo.gl/G13TEw > Acesso em: 16 jan. 2016.

BRASIL. Piauí $\gg$ Cajueiro da Praia. 2016b. Disponível em: < http://cod.ibge.gov.br/3DRX > Acesso em: 30 jan. 2016.

BRASIL. Piauí >> Cajueiro da Praia > infográficos: despesas e receitas orçamentárias e pib. 2014b. Disponível em: < https://goo.gl/PczPf9 > Acesso em: 10 fev. 2016.

CABO, A.R. Planificación territorial del turismo. In. SEABRA, G. (Org.). Turismo de base Local: identidade cultural e desenvolvimento regional. João Pessoa: Ed. Universitária/UFPB, 2007, p. 241-248.

CACHO, A.N.B.; AZEVEDO, F.F. O turismo no contexto da sociedade informacional. Revista Brasileira de Pesquisa em Turismo, v.4, n.2, p. 31 48, ago. 2010.

CANCLINI, NG. Culturas híbridas: estratégias para entrar e sair da modernidade. Tradução de Heloísa Pezza Cintrão e Ana Regina Lessa; Tradução da introdução Gênese Andrade. 4. ed. São Paulo: Editora da Universidade de São Paulo, 2008. 
CANCLINI, NG. Diferentes, desiguais e desconectados: mapas e interculturalidades. Tradução de Luiz Sérgio Henriques. 3. ed. Rio de Janeiro: Editora UFRJ, 2009.

CARNEIRO, M.J. Do "rural" como categoria de pensamento e como categoria analítica. In. CARNEIRO, M.J. (Coord.). Ruralidades contemporâneas: modos de viver e de pensar o rural na sociedade brasileira. Rio de Janeiro: Mauad/FAPERJ, 2012. pp. 23-50.

CARNEIRO, M.J. Multifuncionalidade da agricultura e ruralidade: uma abordagem comparativa. In. MOREIRA, J.R.; COSTA, L.F.C. (Orgs.). Mundo rural e cultura. Rio de Janeiro: Mauad, 2002. pp. 223-240.

CARNEIRO, M.J. Pluriatividade da agricultura no Brasil: uma reflexão crítica. In: SCHNEIDER, S. A diversidade da agricultura familiar. Porto Alegre, RS: UFRGS, 2006.

CORIOLANO, L.N.M.T. et al. Arranjos Produtivos Locais do Turismo Comunitário: Atores e Cenários em Mudança. Fortaleza: EdUECE, 2009.

CUNHA, J.M.A.; MÉLO, I.C.; KANITZ, H.G. Turismo pra quem? Considerações acerca do turismo desenvolvido na comunidade Barra Grande, município de Cajueiro da Praia - PI. In: Anais do XIII Encontro Nacional de Turismo de Base Local (ENTBL). Universidade Federal de Juiz de Fora (UFJF). Juiz de Fora, MG, 2014.

FERNANDES, S.W.R. A inserção do espaço geográfico na política de turismo. In. STEINBERGER, M. (Org.). Território, Estado e políticas públicas espaciais. Brasília: LER Editora, 2013.

FERREIRA, D.C.G. A invenção de Barra Grande: construção, transformação e conflitos de um destino turístico no litoral do Piauí. 2012. 168 p. Dissertação (Mestrado). Mestrado em Antropologia e Arqueologia, Centro de Ciências Humanas e Letras, Universidade Federal do Piauí. Teresina, 2012a.

FERREIRA, D.C.G. De quem é o peixe? Representações do pescador e conflitos em Barra Grande, Piauí. Anais do XV Encontro de Ciências Sociais do Norte e Nordeste. Teresina, 2012b.

GIDDENS, A. As consequências da modernidade. Tradução de Raul Fiker. São Paulo: Editora UNESP, 1991.

GIL, A.C. Como elaborar projetos de pesquisa. 4. ed. São Paulo: Atlas, 2002.

GIL, A.C. Métodos e técnicas de pesquisa social. (6a ed.). São Paulo: Atlas, 2008.

HALL, S. A identidade cultural na pós-modernidade. 12. ed. Rio de Janeiro: Lamparina, 2015.

IGNARRA, L.R. Fundamentos do turismo. São Paulo: Pioneira Thomson, 2001.

IRVING, M.A. Sustentabilidade, turismo e sociedade. In. LEITE JÚNIOR, P.P. O valor social do turismo. São Paulo: Roca, 2007. pp. 27-37. 
JAFARI, J. Research and scholarship: the basis of tourism education. Journal of Tourism Studies, v.1, n.1, pp. 33-41. 1990.

KRIPPENDORF, J. Sociologia do turismo: para uma compreensão do lazer e das viagens. 2. ed. São Paulo: Aleph, 2001.

LEFEBVRE, H. De lo rural a lo urbano. 4. ed. Tradução de Javier GonzálezPueyo. Barcelona: Península, 1978.

MACÊDO, E.M. O turismo na praia de Barra Grande-PI: impactos e contribuições ao desenvolvimento local. 2011. 181 p. Dissertação (Mestrado). Mestrado Profissional em Turismo, Centro de Excelência em Turismo, Universidade de Brasília. Brasília, 2011.

MINAYO, M.C.S. O desafio do conhecimento: pesquisa qualitativa em saúde. 12. ed. São Paulo: Hucitec-Abrasco, 2010.

OLIVEIRA, F.M. As políticas de turismo no Brasil nos anos noventa. Turismo em Análise, v.19, n.2, p. 177-200, ago. 2008.

OLIVEIRA, R.J. Turismo backpacker/mochileiro. In. TRIGO, L.G.G. (Org.). Análises regionais e globais do turismo brasileiro. p. 399-422. São Paulo: Roca, 2005.

ORGANIZAÇÃO INTERNACIONAL DO TRABALHO (OIT). Manual para a redução da pobreza por meio do turismo. Geneva, Suíca: Autor, 2011.

PANOSSO NETTO, A.; TRIGO, L.G.G. Cenários do turismo brasileiro. São Paulo: Aleph, 2009.

PREFEITURA MUNICIPAL DE CAJUEIRO DA PRAIA. Relatório Final do Plano Diretor: Município de Cajueiro da Praia - PI. Cajueiro da Praia: Technum Consultoria, 2008.

RUSCHMANN, D.M. Turismo e planejamento sustentável: A proteção do meio ambiente. 8. ed. Campinas, SP: Papirus, 2001.

SANTOS, G.E.O.; KADOTA, D.K. Economia do turismo. São Paulo: Aleph, 2012.

SCHNEIDER, S. Turismo em comunidades rurais: inclusão social por meio de atividades não-agrícolas. In. BRASIL. MINISTÉRIO DO TURISMO (MTUR). Turismo social: uma viagem de inclusão. Rio de Janeiro: IBAM, 2006.

SERVIÇO BRASILEIRO DE APOIO ÀS MICRO E PEQUENAS EMPRESAS DO PIAUÍ (SEBRAE/PI). Plano estratégico de desenvolvimento do turismo no Piauí - 2012/2020. SEBRAE/PI: Teresina, 2012.

SILVA, V. Agronegócio e desenvolvimento em Sebastião Leal - PI: atores, processos e impactos sócio-culturais-ambientais. In. Anais do XXIX Congreso Latinoamericano de Sociología (ALAS). Santiago, Chile, 2013.

TRIGO, L.G.G. A sociedade pós-industrial e o profissional em turismo. 4. ed. Campinas, SP: Papirus, 2000. 
WANDERLEY, M.N.B. A emergência de uma nova ruralidade nas sociedades modernas avançadas - o "rural" como espaço singular e ator coletivo. 2000. Estudos Sociedade e Agricultura. Disponível em: < https://goo.gl/6YvH1k $>$. Acesso em: 10. ago. 2016.

WANDERLEY, M.N.B. Um saber necessário: os estudos rurais no Brasil. Campinas, SP: Editora da Unicamp, 2011.

\section{Notas:}

1 Roteiro turístico em que um condutor de visitantes leva os turistas aos locais em que são encontrados os cavalos-marinhos, retirando-os do ambiente natural através de um instrumento feito de vidro (semelhante a um pequeno aquário) e torna visível aos turistas, que tiram fotos. A viabilidade da prática desse roteiro é questionada, pois muitos ambientalistas alertam para os riscos que o animal sofre, podendo leva-lo à morte e a consequente extinção, dada a sensibilidade dos animais.

2 O efeito multiplicador sobre a renda, na perspectiva de Krippendorf (2001) e Ignarra (2001) leva em consideração os movimentos financeiros (empregos, investimentos e circulação) alocados sobre a destinação turística receptora e/ou emissora. Do ponto de vista político, este é um aspecto comumente reproduzido no discurso hegemônico empresarial, na disputa pelos dividendos advindos de incentivos fiscais e financeiros à instalação dos projetos globais de turismo.

3 Encontramos paralelo no estado do Piauí quanto ao controle político estabelecido por grupos externos observando o que ocorre na região Sul, na região dos cerrados piauienses, em que grupos dominantes chegam ao limite de propor a divisão do estado em dois, criando o estado do Gurguéia, com vistas a hegemonizar o comando local e regional dos interesses em disputa (SILVA, 2013).

José Maria Alves da Cunha: Universidade Federal do Piauí, Teresina, PI, Brasil.

E-mail: jmacunha1@hotmail.com

Link para o currículo Lattes: http://lattes.cnpq.br/0098715118514336

Marlúcia Valéria da Silva: Universidade Federal do Piauí, Teresina, PI, Brasil.

E-mail:valeriasil@uol.com.br

Link para o currículo Lattes: http://lattes.cnpq.br/1081387367108030

Data de submissão: 30 de agosto de 2016

Data de recebimento de correções: 15 de maio de 2018

Data do aceite: 15 de maio de 2018

Avaliado anonimamente 